\title{
Türkiye'de İnşaat Sektöründe Meydana Gelen İş Kazalarının Analizi
}

\author{
Hüseyin Ceylan \\ Kırıkkale Meslek Yüksekokulu, Kırıkkale Üniversitesi, Kırıkkale, 71451 Türkiye. \\ Telefon: 0 (318) 357-4242; Fax: 0 (318) 357-2923, husceylan@ hotmail.com
}

\begin{abstract}
Özet - İnşaat sektörü iş güvenliği açısından en tehlikeli işkollarından birisidir. Bu çalışmada Türk inşaat sektörünün iş güvenliği açısından genel görünümü ortaya konulmakta; inşaat sektöründe meydana gelen kazalar ile Türkiye genelinde meydana gelen kazalar; uluslararası kaza istatistikçilerinin de kullandığı Genel Kaza Slklı̆̆g, Ölümlü Kaza Siklı̆̆l, Sürekli İs Göremezlik Kaza Siklı̆g gibi karşılaştırma ölçütleri kullanılarak kıyaslanmaktadır. Ayrıca Türk inşaat sektöründe meydana gelen kazalar, çeşitli ülkelerin inşaat sektörlerinde meydana gelen kazalarla karşılaştırılmıştır. Analizler sonucunda Türkiye'de inşaat sektöründe meydana gelen iş kazalarının önemi ortaya konulmuş ve bu sektörde iş kazalarının önlenmesine yönelik alınması gereken tedbirler önerilmiştir. İnşaat sektörünün hızla geliştiği Türkiye'de, iş kazalarının önlenmesi için gerekli tedbirlerin alınmasının ne kadar önem arz ettiği, çalışmada sunulan sayısal veriler ile desteklenmektedir.
\end{abstract}

Anahtar Kelimeler: İş Kazaları, İş Güvenliği, İnşaat, Türkiye.

Abstract - Construction industry is one of the most dangerous sectors. In this study, the general assessment of the Turkish construction sector in terms of job safety are exposed; all the accidents which occurred in Turkey and the accidents which occurred in Turkish construction sector were compared in terms of the parameters such as general incidence rate, fatal incidence rate and permanent incapacity incidence rate, which are also used by international accident statisticians. Moreover, the accidents occurred in Turkish construction sector have been compared with accidents occurring in construction sectors of various countries. As a result of this analysis, importance of work-related accidents that occurred in the Turkish construction sector has been presented and some recommendations have been made to prevent or reduce occupational accidents in this sector. In Turkey where the construction industry has been rapidly developing and how vital it is to take necessary measures for the prevention of work-related accidents is supported by the numerical data presented in this study.

Keywords: Occupational Accident, Job Safety, Construction, Turkey.

\section{GiRiş VE AMAÇ}

ünyada ve Türkiye'de iş kazaları çok ciddi bir problem olarak karşımıza çıkmaktadır. İş kazaları, bütün ülkelerin ortak sorunu olmasına rağmen, gerekli önlemlerin alınmasıyla beraber belli oranlarda azaltılabilir. $\mathrm{Bu}$ önlemlerin alınmasında yetersiz kalan ülkeler kazalardan daha fazla etkilenmektedir[1,2,3,4].

İş kazalarının en önemli sonucu, çalışanların ölmesi, yaralanması veya sakat kalmasıdır. Bunun yanında çok ciddi maddi kayıplar da iş kazalarının diğer önemli bir sonucudur[1,2,3,4]. Türkiye'de iş sağlığ 1 ve iş güvenliği hususunda çok ciddi ilerlemeler kat edilmesine rağmen, bu konuyla ilgili olarak yapılması gereken çok şeyin olduğu da yadsınamaz bir gerçektir. Son yıllarda çalışan kişi sayısına oranla kaza sayıları azalmaktadır. Ancak, son yedi yılın kaza istatistikleri incelendiğinde hâlâ ülkemizde y1lda ortalama 73992 iş kazası olmakta ve bu kazalarda 1152 çalışanın hayatını kaybettiği görülmektedir. Ayrıca bu kazaların ülkemize getirdiği maddi kaybın da 45 milyar TL/yıl civarında olduğu tahmin edilmektedir $[5,6,7,8,9,10,11,12,13]$.

Tüm dünyada olduğu gibi Türkiye'de de kazaların yoğunlaştığı sektörler vardır[14]. İnşaat en tehlikeli işkollarından birisidir. Uluslararası Çalışma Örgütü (ILO) verilerine göre inşaat işçileri, diğer sektörlerde çalışan işçilere oranla 3-6 kat daha fazla kazaya uğrama riski taşımaktadırlar[15,16]. Ülkemizde inşaat sektörü gerek ölümlü, gerekse sürekli iş göremezlik kaza sıklığının en fazla olduğu sektördür. Sosyal Güvenlik Kurumu (SGK) verilerine göre, ülkemizde bir yılda gerçekleşen tüm iş kazalarının yaklaşık \%9'u, sürekli iş göremezliklerin $\% 18^{\prime} \mathrm{i}$ ve ölümlü iș kazalarının \% 28'i inșaat ișlerinde gerçekleşmektedir[7,8,9,10,11,12,13]. Çalışma ve Sosyal Güvenlik Bakanlığı'nın iş kazalarıyla mücadele açısından belirlediği öncelikli üç sektörden birisi de inşaat sektörüdür [17]. Ayrıca Çalışma ve Sosyal Güvenlik Bakanlığının hazırlamış olduğu Tehlike Sınıfları Yönetmeliği'ne göre inşaat sektörü "Çok Tehlikeli İşler" sınıfında yer almaktadır[18].

İş güvenliği açısından inşaat sektörünü bu kadar tehlikeli hale getiren risklere çözüm üretebilmek için mevcut 
durumun daha detaylı analiz edilmesine ihtiyaç vardır. Bu çalışmada, belirtilen amaçtan yola çıkarak 2004-2010 dönemine ait 7 yıllık SGK iş kazası verileri incelenmiş, Türkiye genelinde meydana gelen kazalar ile inşaat sektörü kazaları, uluslararası kaza istatistikçilerin de kullandığ çeşitli parametreler açısından kıyaslanmıştır. 2011 yılına ait kaza istatistikleri henüz tamamlanmadığı için değerlendirmeye alınmamıştır. Ayrıca, Türk İnşaat sektöründe meydana gelen kazalar, çeşitli ülkelerin inşaat sektörlerinde meydana gelen kazalarla karşılaştırılmıştır.

\section{II. İNŞAAT SEKTÖRÜ VE İş GÜVENLIĞİ RISKLERİ}

İnşaat sektörü çalışanları iş güvenliği açısından önemli risklerle karşı karşıyadırlar. Bu riskler, ülkemizin genel teknolojik ve sosyo-ekonomik yapısının yanında, inşaat işkolunun kendine özgü koşullarından da kaynaklanmaktadır. Bu özgün koşullar;

* İnşaat firmalarının çoğunlukla kurumsallaşmanın zayıf olduğu küçük ve orta ölçekli işletmeler olması,

* İnşaat işlerinin kısa süreli ve dinamik bir yapıya sahip olmas1,

* İnşaat işlerinin doğal iklim koşulları altında gerçekleştirilmesi,

* Çalışma koşullarının bir işyerinden diğerine değişkenlik göstermesi,

* Çalışma sahasının geniş ve dağınık olması,

* İş çeşitliliği ve her bir işin kendine özgü riskler içermesi,

* İşlerin genellikle farklı firmalar tarafindan gerçekleştirilmesi, sahada birden fazla işveren ve/veya taşeron bulunması,

* Çalışanların ve kullanılan malzemelerin sürekli hareket halinde olması ve bu hareketliliğin sistematik olmaması,

* Zemin seviyesinin altında veya yüksekte çalışılması,

* İşçi devir hızının fazla olması,

* Çalışanların eğitim ve bilinç düzeylerinin düşük olması,

* Yaptığı işle ilgili herhangi bir mesleki eğitim almayan çalışanların çokluğu,

* Teknolojik gelişmelere rağmen, halen insan gücünün yoğun bir şeklide kullanılması şeklinde özetlemek mümkündür[19,20,21,22].

\section{III. İNŞAAT SEKTÖRÜN İș GÜVENLIĞİ AÇISINDAN GENEL GÖRÜNÜMÜ}

\section{A. Çalışan Sayıları}

2004-2010 SGK istatistik y1llkklarından elde edilen kaza verilere göre, Türkiye geneli ve İnşaat sektöründe çalş̧an sigortalı sayıları ve \% değerleri Tablo I'de verilmiştir $[7,8,9,10,11,12,13]$.
TABLO I

ÇALIŞAN SAYILARI VE YÜZDELERİ

\begin{tabular}{|c|c|c|c|c|}
\hline YIL & Türkiye Geneli & \% & Inşaat Sektörü & \% \\
\hline 2004 & 6.181 .251 & $\mathbf{1 0 0}$ & 752.136 & $\mathbf{1 2 , 1 6}$ \\
\hline 2005 & 6.918 .605 & $\mathbf{1 0 0}$ & 933.498 & $\mathbf{1 3 , 4 9}$ \\
\hline 2006 & 7.818 .642 & $\mathbf{1 0 0}$ & 1.185 .723 & $\mathbf{1 5 , 1 6}$ \\
\hline 2007 & 8.505 .390 & $\mathbf{1 0 0}$ & 1.247 .970 & $\mathbf{1 4 , 6 7}$ \\
\hline 2008 & 8.802 .989 & $\mathbf{1 0 0}$ & 1.238 .888 & $\mathbf{1 4 , 0 7}$ \\
\hline 2009 & 9.030 .202 & $\mathbf{1 0 0}$ & 1.227 .689 & $\mathbf{1 3 , 5 9}$ \\
\hline 2010 & 10.030 .810 & $\mathbf{1 0 0}$ & 1.450 .291 & $\mathbf{1 4 , 4 5}$ \\
\hline
\end{tabular}

Bu tablo incelendiğinde, 2004'ten 2010'a hem Türkiye genelinde hem de inşaat sektöründe çalışan sayılarında ciddi bir artışın olduğu söylenebilir. İnşaat sektöründe 2010 yılındaki çalışan sayısı 2004'e göre yaklaşık olarak \% 92 artmıştır. Sektör, 1.450.291 çalışanı ile tüm ülke işgücünün yaklaşı $\% 15$ 'ini istihdam etmekte ve bu oran ile ülkemizde en fazla istihdamın sağlandığı sektör olarak görülmektedir. $\mathrm{Bu}$ yönüyle inşaat sektörü ülkemizin lokomotif sektörlerinden biridir.

\section{B. İş Kazası Sayıları}

2004-2010 SGK istatistik yıllıklarından elde edilen kaza verilerine göre, Türkiye geneli ve inşaat sektöründe meydana gelen iş kazaları sayıları ve \% değerleri Tablo II'de verilmiştir[7,8,9,10,11,12,13].

TABLO II

İs KAZASI SAYILARI VE YÜZDELERI

\begin{tabular}{|c|c|c|c|c|}
\hline YIL & Türkiye Geneli & $\mathbf{\%}$ & İnşaat Sektörü & $\mathbf{\%}$ \\
\hline 2004 & 84.210 & $\mathbf{1 0 0}$ & 8.106 & $\mathbf{9 , 6 2}$ \\
\hline 2005 & 73.923 & $\mathbf{1 0 0}$ & 6.480 & $\mathbf{8 , 7 6}$ \\
\hline 2006 & 79.027 & $\mathbf{1 0 0}$ & 7.143 & $\mathbf{9 , 0 3}$ \\
\hline 2007 & 80.602 & $\mathbf{1 0 0}$ & 7.615 & $\mathbf{9 , 4 4}$ \\
\hline 2008 & 72.963 & $\mathbf{1 0 0}$ & 5.574 & $\mathbf{7 , 6 3}$ \\
\hline 2009 & 64.316 & $\mathbf{1 0 0}$ & 5.132 & $\mathbf{7 , 9 7}$ \\
\hline 2010 & 62.903 & $\mathbf{1 0 0}$ & 6.437 & $\mathbf{1 0 , 2 3}$ \\
\hline Ortalama & 73.992 & $\mathbf{1 0 0}$ & 6.641 & $\mathbf{8 , 9 5}$ \\
\hline
\end{tabular}

$\mathrm{Bu}$ tablo incelendiğinde, hem Türkiye genelinde hem de inşaat sektöründe kaza sayılarında özellikle son yıllarda ciddi bir azalmanın olduğu söylenebilir. Türkiye genelinde 2010 yılındaki kaza sayısı yaklaşık olarak 2004'e göre \%25, 2007'e göre \%22, 2008'e göre \%14 azalmıştır. İnşaat sektöründe ise 2010 yılındaki kaza sayısında 2004'e göre yaklaşık olarak \%21'lik bir azalma gözlenmektedir. Bu durum özellikle Avrupa Birliği sürecinde ülkemizde alınan iş güvenliği tedbirlerinin etkinliğini göstermesi açısından önemlidir.

İnşaat sektörünün tüm kazalar içerisindeki oran1 incelendiğinde, aşağı-yukarı ciddi bir değişimin olmadığı söylenebilir. İnşaat işkolunun tüm çalışanların \%15'ini istihdam etmesine karşılık, tüm kazaların sadece yaklaşık \%9'unun bu sektörde olması, genel kaza sıklığı açısından inşaat sektörünün Türkiye geneline göre daha iyi bir durumda olduğunu da göstermektedir. Ancak ülkemizdeki inşaat şirketlerinin genellikle küçük ve orta ölçekli işletmeler olduğu, bu tür işletmelerde sigortasız işçi 
çalıştırma oranının büyük işletmelere kıyasla daha fazla olduğu, kaçak olarak çalıştırılan iş̧̧ilerin geçirdikleri kazaların SGK kayıtlarına geçmediğini de unutmamak gerekir.

\section{C. İ̧̧ Kazası Sonucu Ölüm Vakası Sayıları}

2004-2010 SGK istatistik y1lliklarından elde edilen kaza verilerine göre, Türkiye geneli ve inşaat sektöründe meydana gelen iş kazaları sonucu olan ölüm sayıları ve \% değerleri Tablo III'de verilmiştir [7,8,9,10,11,12,13].

TABLO III

ÖLÜM SAYILARI VE YÜZDELERİ

\begin{tabular}{|c|c|c|c|c|}
\hline YIL & Türkiye Geneli & $\mathbf{\%}$ & İşaat Sektörü & \% \\
\hline 2004 & 843 & $\mathbf{1 0 0}$ & 263 & $\mathbf{3 1 , 1 9}$ \\
\hline 2005 & 1.096 & $\mathbf{1 0 0}$ & 290 & $\mathbf{2 6 , 4 5}$ \\
\hline 2006 & 1.601 & $\mathbf{1 0 0}$ & 397 & $\mathbf{2 4 , 7 9}$ \\
\hline 2007 & 1.044 & $\mathbf{1 0 0}$ & 359 & $\mathbf{3 4 , 3 8}$ \\
\hline 2008 & 866 & $\mathbf{1 0 0}$ & 297 & $\mathbf{3 4 , 2 9}$ \\
\hline 2009 & 1.171 & $\mathbf{1 0 0}$ & 156 & $\mathbf{1 3 , 3 2}$ \\
\hline 2010 & 1.444 & $\mathbf{1 0 0}$ & 475 & $\mathbf{3 2 , 8 9}$ \\
\hline Ortalama & $1.152,14$ & $\mathbf{1 0 0}$ & 319,57 & $\mathbf{2 8 , 1 9}$ \\
\hline
\end{tabular}

Yukarıda verilen Tablo-II ve Tablo-III beraber incelendiğinde, 2004'ten 2010'a Türkiye genelinde ve inşaat sektöründe kaza sayılarında ciddi bir azalma olmasına rağmen kaza sonucu ölüm sayılarında kayda değer bir azalmanın olmadığı, hatta küçük bir artışın olduğu söylenebilir. $\mathrm{Bu}$, incelenmesi gereken dikkate değer bir durumdur. 2009 yılına kadar inşaat sektöründe ölüm sayılarında bir iyileşme olmazken, sadece 2009 yılında dikkat çekici bir azalma olmuştur.

SGK kaza istatistiklerine göre, ülkemizde en fazla ölüm vakası inşaat sektöründe yaşanmaktadır. İnşaat sektörü ortalama yıllık 320 ölüm vakası ile en tehlikeli sektör olarak karşımıza çıkmaktadır. İnşaat ișkolunun tüm çalışanların \%15'ini istihdam etmesine karşın, tüm ölüm vakalarının yaklaşım \%28'inin bu sektörde olması ölümlü kaza sıklı̆̆ açısından inşaat sektörünün nasıl bir durumda olduğunu da göstermektedir. Özellikle inşaat sektörü gibi ölüm vakalarının fazla olduğu sektörler üzerinde hassasiyetle durulması gereği ortadadır. Çalışanların can güvenliği sorununun gerçek nedenlerinin tespit edilerek, buna göre gerekli önlemlerin alınabilmesi için SGK'nın tüm kaza raporlarını, iş güvenliği uzmanlarının ve araştırmacıların kullanımına açması gerekmektedir. İnşaat sektöründe yapılan periyodik denetimlerin sayısının artırılması bu sorun için akla gelen önemli bir çözüm olarak görülmektedir. Ölümcül kazaların fazla olduğu sektörlerde; özellikle ölümlü kazaların kök nedenlerinin tespit edilmesi, bu verilerin benzer kazaların tekrarlanmaması için ulusal sektörel bir veri havuzunda toplanması ve bu bilgilere o sektörde faaliyet gösteren tüm kuruluşların erişiminin sağlanması başka bir çözüm olabilir. Yine ölümlü kazaların fazla olduğu sektörlere mahsus ek iş güvenliği tedbirleri de ilave edilebilir. Örneğin inşaat sektöründe en önemli ölümlü kaza nedeni "Yüksekten Düşme" faktörü olduğu için, belirli bir yaşın üzerinde olan çalışanların yüksekte çalışmaları yasaklanabilir veya bu çalışanların daha sık sağlık kontrolünden geçirilmesi istenebilir.

\section{Sürekli İş Göremezlik Saylları}

Sürekli iş göremezlik, bir iş kazası sebebiyle yapılan tedavi sonunda çalışanın meslekte kazanma gücünün tamamının veya bir kısmının kaybedilmiş olması halidir. Bir başka deyişle çalışanın ömür boyu sakat kalması durumunu ifade eder.

2004-2010 SGK istatistik y1llklarından elde edilen kaza verilerine göre, Türkiye geneli ve inşaat sektöründe meydana gelen iş kazaları sonucu ortaya çıkan sürekli iş göremezlik sayıları ve \% değerleri Tablo IV'de verilmiştir $[7,8,9,10,11,12,13]$.

TABLO IV

SÜREKLI İS GÖREMEZLIK SAYILARI VE YÜZDELERI

\begin{tabular}{|c|c|c|c|c|}
\hline YIL & Türkiye Geneli & $\mathbf{\%}$ & İşaat Sektörü & \% \\
\hline 2004 & 1.693 & $\mathbf{1 0 0}$ & 349 & $\mathbf{2 0 , 6 1 4}$ \\
\hline 2005 & 1.639 & $\mathbf{1 0 0}$ & 324 & $\mathbf{1 9 , 7 6}$ \\
\hline 2006 & 2.267 & $\mathbf{1 0 0}$ & 428 & $\mathbf{1 8 , 8 7}$ \\
\hline 2007 & 1.956 & $\mathbf{1 0 0}$ & 364 & $\mathbf{1 8 , 6 0}$ \\
\hline 2008 & 1.694 & $\mathbf{1 0 0}$ & 377 & $\mathbf{2 2 , 2 5}$ \\
\hline 2009 & 1.885 & $\mathbf{1 0 0}$ & 241 & $\mathbf{1 2 , 7 8}$ \\
\hline 2010 & 2.085 & $\mathbf{1 0 0}$ & 319 & $\mathbf{1 5 , 2 9}$ \\
\hline Ortalama & $1.888,43$ & $\mathbf{1 0 0}$ & 343,14 & $\mathbf{1 8 , 3 1}$ \\
\hline
\end{tabular}

Tablo IV incelendiğinde 2004'ten 2010'a Türkiye genelinde ve inşaat sektöründe sürekli iş göremezlik sayılarında kayda değer bir değişmenin olmadığ 1 söylenebilir. Ülkemizde en fazla sürekli iş göremezlik vakası ortalama \% 18 ile inşaat sektöründe yaşanmaktadır [6]. İş kazaları nedeniyle her yıl ortalama 343 inşaat çalışanı ömür boyu sakat kalmaktadır. $\mathrm{Bu}$ durum, inşaat sektöründeki kazaların sonuçları itibariyle ciddi kazalar olduğunu göstermektedir.

\section{IV. İNŞAAT SEKTÖRÜ KAZALARININ TÜRKIYE GENELİ İLE KIYASLANMASI}

Ülkeleri, sektörleri ya da fabrikaları yalnızca kaydedilen iş kazası, ölüm veya sürekli iş göremezlik vaka sayıları ya da kaybedilen iş günü sayısı gibi parametrelere bakarak karşılaştırmak mümkün değildir. Çünkü her ülkede, sektörde ya da fabrikada aynı sayıda iş̧̧i çalışmamaktadır. Örneğin on milyondan fazla sigortalı çalışanı olan Türkiye ile nüfusu on milyondan daha az olan Yunanistan'1 sadece kaza, ölüm veya sürekli iş göremezlik vaka sayılarına bakarak, iş güvenliği açısından kıyaslayamayız. Kıyaslamada önemli olan kaç kişinin kazaya uğradığı değil, kazaya uğrayan çalışan sayısının incelenen çalışan grubu içindeki oranıdır. Bu nedenden dolayı, iş kazaları ile ilgili karşılaştırmalarda, çeşitli kıyaslama ölçütleri kullanılmaktadır. 
Avrupa Topluğu İstatistik Ofisi (Eurostat) tarafindan iş kazaları ile ilgili istatistiklerin hazırlanmasında kullanılmak üzere geliştirilen dokümanda, "kaza sıklığı" kavramı yer almakta ve 100.000 çalışan başına düşen iş kazası sayısı olarak tanımlanmaktadır. $\mathrm{Bu}$ çalışmada, üç farklı kaza sıklığı değeri hesaplanmıştır[16,23].

Toplam is kazasl saylsl için hesaplanan genel kaza slklık değeri $\left(K_{S 1}\right)$;

bir yılda 100.000 çalışan başına düşen iş kazası sayısı olarak tanımlanmaktadır. $K_{S 1}$ değeri,

$K_{S 1}=\frac{K S * 100000}{C \dot{I} S}$

formülü ile hesaplanmaktadır. Burada KS kaza sayısın; ÇİS çalışan işçi sayısını göstermektedir.

İs kazasl sonucu ölüm vakasl saylsı için hesaplanan ölümlü kaza sıklık dĕgeri $\left(K_{S 2}\right)$;

bir yılda 1.000 .000 çalışan başına düşen ölüm sayısı olarak tanımlanmaktadır. $K_{S 2}$ değeri,

$$
K_{S 2}=\frac{\ddot{O} S * 1000000}{C \zeta \dot{I} S}
$$

formülü ile hesaplanmaktadır. Burada ÖS ölüm vakası sayısını, ÇİS çalışan işçi sayısını göstermektedir.

Ölümlü kaza sıklık değerleri, bir yıl içerisinde, her 1000000 işçiden kaçının iş kazası sonucu öldüğünü ifade eden bir gösterge olduğu için çok çok önemlidir. Çünkü hiçbir maddi değer insan hayatından daha kıymetli değildir. Ayrıca, ölümlü kazalar çalışanları yaptıkları işten soğuttuğu için, hem işten ayrılmaların artmasına hem de verim düşüşlerine sebep olmaktadır.

IS kazasl sonucu sürekli iș göremezlik saylsl için hesaplanan sürekli is göremezlik kaza sıklık değeri $\left(K_{S 3}\right)$; bir yılda 1.000 .000 çalışan başına düşen sürekli iş göremezlik sayısı olarak tanımlanmaktadır. $K_{S 3}$ değeri,

$$
K_{S 3}=\frac{S I G S * 1.000 .000}{C ̧ I S}
$$

formülü ile hesaplanmaktadır. Burada SIGS sürekli iş göremezlik sayısını, ÇIS çalışan işçi sayısını göstermektedir.
2004-2010 yılları için Türkiye geneli ve inşaat sektörü için hesaplanan genel kaza sıklığı, ölümlü kaza sıklığı ve sürekli iş göremezlik kaza sıklığı değerleri sırasıyla Tablo V, Tablo VI ve Tablo VII'de verilmiştir $[7,8,9,10,11,12,13]$.

TABLO V

GENEL KAZA SIKLIĞI

\begin{tabular}{|c|c|c|}
\hline YIL & Türkiye Geneli & İnşaat Sektörü \\
\hline 2004 & 13,62 & 10,78 \\
\hline 2005 & 10,68 & 6,94 \\
\hline 2006 & 10,11 & 6,03 \\
\hline 2007 & 9,48 & 6,10 \\
\hline 2008 & 8,29 & 4,50 \\
\hline 2009 & 7,12 & 4,18 \\
\hline 2010 & 6,27 & 4,74 \\
\hline
\end{tabular}

TABLO VI

ÖLÜMLÜ KAZA SIKLIĞI

\begin{tabular}{|c|c|c|}
\hline YIL & Türkiye Geneli & İnşaat Sektörü \\
\hline 2004 & 136 & 350 \\
\hline 2005 & 158 & 310 \\
\hline 2006 & 205 & 330 \\
\hline 2007 & 123 & 287 \\
\hline 2008 & 98 & 240 \\
\hline 2009 & 130 & 127 \\
\hline 2010 & 144 & 328 \\
\hline
\end{tabular}

TABLO VII

SÜREKLi İS GÖREMEZLIK KAZA SIKLIĞI

\begin{tabular}{|c|c|c|}
\hline YIL & Türkiye Geneli & Inşaat Sektörü \\
\hline 2004 & 274 & 460 \\
\hline 2005 & 237 & 347 \\
\hline 2006 & 290 & 360 \\
\hline 2007 & 230 & 290 \\
\hline 2008 & 192 & 300 \\
\hline 2009 & 209 & 196 \\
\hline 2010 & 208 & 220 \\
\hline
\end{tabular}

Tablo V'e bakıldığında, 2004'ten 2010'a kadar hem Türkiye geneli için, hem de inşaat sektörü için hesaplanan genel kaza sıklığı değerlerinde ciddi bir azalma gözlenmektedir. 2004 yılında inşaat sektöründe çalışan her 100.000 kişiden yaklaşık 11 'i iş kazasına maruz kalırken, 2010 yılında bu değer yaklaşık 5'e gerilemiştir.

Tablo VI incelendiğinde, 2004'ten 2010'a kadar hem Türkiye geneli için, hem de inşaat sektörü için hesaplanan ölümlü kaza sıklığı değerlerinde, ciddi bir iyileşmenin olmadığı, bu değerin dalgalı bir seyir izlediği gözlenmektedir. 2004 yılında inşaat sektöründe çalışan her 1.000.000 kişiden 350'si iş kazası sonucu hayatını yitirirken, 2010 yılında bu değer 328'e gerilemiştir.

Tablo VII'den de anlaşılacağı üzere, 2004'ten 2010'a kadar inşaat sektöründe sürekli iş göremezlik kaza sıklığı değerlerinde dikkate değer bir iyileşme gözlenmektedir. Türkiye genelinde ise tedrici bir azalmadan bahsedilebilir. 2004 yılında inşaat sektöründe çalışan her 1.000 .000 kişiden 460'1 iş kazası sonucu sürekli iş göremez hale gelirken, 2010 yılında bu değer 220'ye gerilemiştir. 2004-2010 y1lı ortalamasına bakılırsa hala İnşaat sektörü sürekli iş 
göremezlik kaza sıklığı açısından Türkiye ortalamasının üzerinde seyretmektedir. Sadece 2009 yılında inşaat sektörü için hesaplanan değer Türkiye ortalamasının altında görülmektedir.

Tablo V, Tablo VI ve Tablo VII beraber değerlendirildiğinde aslında inşaat sektöründe Türkiye ortalamasına göre daha az kazanın meydana geldiği ancak çok daha fazla ölüme ve sakat kalmaya sebebiyet verdiği görülür. Bunun için, inşaat sektörü kazalarının sonuçları itibariyle önemli kazalar olduğu söylenebilir. İnşaat sektörü için hesaplanan genel kaza sıklığı değerleri, analizin yapıldığı tüm yıllar için Türkiye geneline göre daha düşüktür.

\section{TÜRK İNŞAAT SEKTÖRÜNÜN İS GÜVENLİĞİ AÇISINDAN DÜNYADAKI DURUMU}

$\mathrm{Bu}$ çalışmada, Türk inşaat sektörünün iş güvenliği açısından dünya genelindeki mevcut durumunu görmek için, çeşitli ülkelerin inşaat sektörlerinde meydana gelen kazalarla karşılaştırılması yapılmıştır. Burada SGK, ILO ve Amerikan İşçi İstatistikleri bürosu verilerinden faydalanarak pek çok ülkenin inşaat sektörleri için ölümlü kaza sıklığı değerleri hesaplanmıştır $[7,8,9,10,11,12,13,15,24]$. Çeşitli ülkelerin inşaat sektörü için hesaplanan ölümlü kaza sılklığı değerleri Tablo VII'de verilmiştir. ILO kaza istatistiklerinde 2004-2010 yıllarına ait tüm veriler mevcut olmadığı için, bazı yıllar için ölümlü kaza sıklığı değerleri hesaplanamamıştır.

TABLO VIII

ÇEŞiTLi ÜLKELERIN İNŞAAT SEKTÖRLERI İÇIN HESAPLANAN ÖLÜMLÜ KAZA SIKLIĞI DEĞERLERİ

\begin{tabular}{|l|l|l|l|l|l|l|l|}
\hline \multicolumn{1}{|c|}{ Ülke } & 2004 & 2005 & 2006 & 2007 & 2008 & 2009 & 2010 \\
\hline ABD & 120 & 110 & 110 & 110 & 100 & 97 & 94 \\
\hline Türkiye & $\mathbf{3 5 0}$ & $\mathbf{3 1 0}$ & $\mathbf{3 3 0}$ & $\mathbf{2 8 7}$ & $\mathbf{2 4 0}$ & $\mathbf{1 2 7}$ & $\mathbf{3 2 8}$ \\
\hline İtalya & 140 & 140 & 150 & 110 & 100 & ---- & ---- \\
\hline Íspanya & 135 & 140 & 121 & 110 & 106 & ---- & ---- \\
\hline Romanya & $\mathbf{2 4 0}$ & $\mathbf{3 4 0}$ & $\mathbf{2 6 0}$ & $\mathbf{3 5 0}$ & $\mathbf{3 2 0}$ & ---- & ---- \\
\hline Kanada & 101 & 109 & 95 & 82 & 87 & ---- & ---- \\
\hline Bulgaristan & 224 & 203 & 191 & 184 & 200 & ---- & ---- \\
\hline Macaristan & 178 & 124 & 109 & 136 & 132 & ---- & ---- \\
\hline Avusturya & 132 & 166 & 171 & 125 & 120 & ---- & ---- \\
\hline Finlandiya & 85 & 98 & 73 & 59 & ---- & --- & ---- \\
\hline Norveç & 13 & 70 & 50 & 28 & 33 & ---- & ---- \\
\hline
\end{tabular}

Tablo VIII'den de anlaşılacağı üzere, Türk inşaat sektörü, Romen inşaat sektörü hariç burada değerlendirilen 11 ülke arasında tüm yıllar için en olumsuz bir tabloya sahip ülke olarak görülmektedir. 2004 yılında Türkiye'de her bir milyon inşaat çalışanından 350'si iş kazalarında hayatını kaybederken, bu değer Norveç'te 13, Finlandiya'da 85, Kanada'da 101, Amerika Birleşik Devletlerinde 120 olarak kaydedilmiştir. Teknolojik gelişimi Türkiye'nin gerisinde olan Macaristan, Bulgaristan gibi ülkelerde bile ölümlü kaza sıklığının bizden düşük olması dikkate değer bir sonuçtur. Her ne kadar Macaristan, Bulgaristan gibi ülkelerin iş kazalarını kayıt altına alma oranları Türkiye ile aynı olmasa da, Türkiye'deki iş güvenliği mekanizmasının yeniden değerlendirilmeye ihtiyaç duyduğu ortadadır.

Ayrıca, Tablo VIII'den çıkarılabilecek bir diğer sonuç; ülkemizdeki iş güvenliği mekanizmasının etkinliğinin, Norveç, Finlandiya gibi dünyada iş güvenliği tedbirlerinin en sıkı bir şekilde uygulandığı ülkeler seviyesine çıkarılabildiğinde, yüzlerce çalışanımızın iş kazaları neticesinde ölmesine engel olunabileceği gerçeğidir.

\section{SONUÇ TARTIŞMA VE ÖNERILER}

Bu çalışmada, Türk inşaat sektörünün içinde bulunduğu durumu ortaya koyabilmek için uygulamadaki iş güvenliği koşullarının yansıması olan iş kazaları istatistikleri değerlendirilmiştir. Bu amaçla en kapsamlı ve resmi kaynak olan SGK istatistik yıllıklarından faydalanılmıştır. Araştırma sonucunda aşağıdaki bulgular elde edilmiştir:

*. Türkiye'de inşaat sektörü tüm çalışanların \%15'ini istihdam eden, ekonomik olarak onlarca sektörü tetikleyen vazgeçilmez bir sektördür. Sosyal Güvenlik Kurumu verilerine göre, ülkemizde bir yılda gerçekleşen tüm iş kazalarının yaklaşık \%9'u, sürekli iş göremezliklerin \% 18 'i ve ölümlü iş kazalarının \% 28 'i inşaat işlerinde gerçekleşmektedir.

* Ülkemizde en fazla ölüm vakası inşaat sektöründe yaşanmaktadır.

* Türkiye'de bir inşaat çalışanının iş kazasına maruz kalma riski ortalama bir Türk çalışanından daha düşük olmasına karşın, ölüm veya ömür boyu sakat kalma riski çok çok daha fazladır. Yani inşaat sektörü kazaları sonuçları itibariyle ehemmiyetli kazalardır.

* Tüm dünyada olduğu gibi Türkiye'de de inşaat sektörü en tehlikeli işkollarından birisidir. Ancak iş güvenliği mekanizmalarının sağlıklı bir şekilde çalıştığı Norveç, Finlandiya, ABD gibi ülkelerle kıyaslandığında, Türk inşaat sektörünün çok daha tehlikeli olduğu ortadadır. Hatta Bulgaristan, Macaristan gibi teknolojik gelişmişlik düzeyi bizden daha geri olan ülkelerden bile daha kötü bir durumda olmamız dikkat çekicidir.

* Maalesef Türkiye genelinde meydana gelen kazaların tamamı kayıt altına alınamamaktadır. Eksik bildirim tüm dünya için olduğu gibi Türkiye için de önemli bir problem olarak karşımıza çıkmaktadır. 82 milyonluk bir nüfusa sahip Almanya'da yılda yaklaşık 800.000 kaza kayıtlara geçerken, 74 milyonluk bir nüfusa sahip Türkiye'de yaklaşık sadece 70.000 kazanın kayıtlara geçmesi bunun en önemli göstergelerindendir. $\mathrm{Bu}$ sebeple iş kazaları açısından Türkiye'nin gerçek durumu, hem inşaat sektörü hem de Türkiye geneli için bu çalışmada verilen rakamlardan çok daha kötü durumdadır.

* SGK tarafından yayınlanan iş kazası istatistik yıllıkları, iş kazalarını sektörel bazda değerlendirerek o sektöre özgü gerçek kaza nedenlerini anlamaya yönelik araştırma yapmak için yetersiz kalmaktadır. Bu nedenle, SGK'nın veri tabanında bulunan tüm kaza verileri, 
araştırmacıların ve akademisyenlerin kullanımına açılmalı, hatta yapılacak araştırmalar, SGK ve ilgili sektör temsilcileri tarafından desteklenmeli, bu çalışmalar sonucunda elde edilen bulgular doğrultusunda iş güvenliği mekanizmaları gözden geçirilmelidir.

* Her sektör için aynı iş güvenliği tedbirlerinin alınması doğru bir yaklaşım değildir. İş kazalarında başı çeken inşaat, maden, elektrik gibi bazı sıkıntılı sektörlerde ayrı standartlar tespit edilmeli ve uygulanmalıdır. Ölümlü kazaların fazla olduğu sektörlere mahsus ek iş güvenliği tedbirleri alınabilir. Örneğin inşaat sektöründe en önemli ölümlü kaza nedeni Yüksekten Düşme faktörü olduğu için, belirli bir yaşın üzerinde olan çalışanların yüksekte çalışmaları yasaklanabilir veya bu çalışanların daha sık sağlık kontrolünden geçirilmesi sağlanabilir.

* Ülkemizde iş güvenliği konusunda denetim yetkisi İş Teftiş Kurulu ve iş müfettişleri'ne verilmiştir. Her yıl Türkiye'deki işyerlerinin sadece \% 6'sının denetlenebilmesi etkin denetim açısından bir sorun oluşturmaktadır. $\mathrm{Bu}$ nedenle, iş müfettişi kadrolarının sayısının artırılması bir çözüm olabilir. Ayrıca her sektör, ilgili alanda uzman olan iş müfettişleri tarafından denetlenmelidir.

* Türkiye'de gerek meslek liselerinde gerekse yükseköğretim kurumlarında iş güvenliği eğitimi çok yetersizdir. Mühendislik fakültelerinin çoğunda iş güvenliği dersi ya hiç okutulmamakta veya seçmeli ders olarak verilmektedir. İş güvenliği uzmanlarının eğitimi için uygulanmakta olan program konuya sektörel açıdan yaklaşmamaktadır. Türkiye'de iş güvenliği uzmanları çeşitli alanlarda eğitim görmüş lisans mezunlarının 220 saatlik bir eğitimden geçirilmesi ile yetiştirilmektedirler. İş güvenliği alanında doğrudan lisans düzeyinde eğitim veren bir birim yoktur. Bunun sonucu olarak da ilgisiz alanlardan mezun olan ve 220 saatlik hızlandırılmış eğitimi tamamlayan birisi inşaat sektöründe iş güvenliği uzmanı olarak çalışabilmektedir. İnşaat sektörüne yeterince vakıf olmayan bu insanlar, güvenli bir çalışma ortamının oluşturulmasında yetersiz kalmaktadırlar. Maden sektöründe olduğu gibi, iş güvenliği mühendisleri muhakkak uzmanlık alanı inşaat mühendisi olan kişiler arasından seçilmeli, başka alanlardan iş güvenliği eğitimi almış insanlar bu sektörde iş güvenliği mühendisi olarak çalıştırılmamalıdır.

\section{KAYNAKLAR}

[1] H.Ceylan, "İmalat Sistemlerindeki İş Kazalarının Tahmini İçin Ağırlıklandırılmış Ortalamalardan Sapma Tekniği”, Gazi Üniversitesi, Fen Bilimleri Enstitüsü, Yayınlanmamış Doktora Tezi, Ankara, 2000.

[2] H. Ceylan, A. Ergüzen, "A Software Program System To Estimate Workplaces Accidents In Production", XIX. World Congress on Safety and Health at Work, Istanbul, TURKEY, 2011.

[3] M. Kurt, "İ̧ Kazalarının Ergonomik Analizi”, Gazi Üniversitesi, Fen Bilimleri Enstitüsü, Yayınlanmamış Doktora Tezi, Ankara, 1993.

[4] M. Kurt, H. Ceylan, "İş Güvenliğinde Tehlike Değerlendirme Teknikleri” Gazi Üniversitesi Fen Bilimleri Enstitüsü Dergisi, October, Vol:14, No:4, pp. 1117-1130, 2001.
[5] H. Ceylan, "Türkiye'deki İs Kazalarının Genel Görünümü ve Gelişmiş Ülkelerle Kıyaslanması', KU IJARED, Volume 3, Issue 2, p.18-24, 2011.

[6] H.Ceylan, "Analysis of Occupational Accidents According To The Sectors in Turkey" Gazi University Journal of Science, 2012. (Accepted, In-press).

[7] SGK (Sosyal Güvenlik Kurumu), "2004 İstatistik Yıllıkları”, SGK Yayını, Ankara, 2004.

[8] SGK (Sosyal Güvenlik Kurumu), "2005 İstatistik Yıllıkları”, SGK Yayını, Ankara, 2005.

[9] SGK (Sosyal Güvenlik Kurumu), "2006 İstatistik Yıllıkları”, SGK Yayını, Ankara, 2006.

[10] SGK (Sosyal Güvenlik Kurumu), "2007 İstatistik Yıllıkları”, SGK Yayını, Ankara, 2007

[11] SGK (Sosyal Güvenlik Kurumu), "2008 İstatistik Yıllıkları", SGK Yayını, Ankara, 2008.

[12] SGK (Sosyal Güvenlik Kurumu), "2009 İstatistik Yıllıkları", SGK Yayını, Ankara, 2009.

[13] SGK (Sosyal Güvenlik Kurumu), "2010 İstatistik Y1llıkları", SGK Yayını, Ankara, 2010.

[14] P. Mitchel, "The Impact of Globalization on Health and Safety at Work", www.wsws.org/articles/1999/jul1999/who-j23.shtml.

[15] ILO (International Labour Office), http://laborsta.ilo.org.

[16] Eurostat, "European Statistics on Accidents At Work (ESAW)", http://europa.eu.int/comm/eurostat.

[17] İSGÜM (İş sağlığı ve güvenliği genel müdürlüğü. http://isag.calısma.gov.tr.

[18] Calıșma ve Sosyal Güvenlik Bakanlığı, "İs Sağlığı ve Güvenliğine İlişkin Tehlike Sınıfları Tebliği”, Resmi Gazete, Sayı: 27320, 2009.

[19] M.E. Öcal, "İnşaat Sektöründe Görülen İş Kazaları", İnşaat Sektöründe İş Sağllğg ve Güvenliği Sempozyumu, 2006.

[20] C.W. Liao, Y.H. Perng, "Data Mining For Occupational Injuries In The Taiwan Construction Industry", Safety Science, Vol:46, pp. 1091-1102, 2008

[21] P. Kines, "Construction Workers' Falls Through Roofs: Fatal Versus Serious Injuries", Journal of Safety Research, Vol:33, pp. 195-208, 2002.

[22] B.Y. Jeong, "Occupational Deaths and Injuries in The Construction Industry”, Applied Ergonomics, Vol:29, pp. 355-360, 1998.

[23] ILO (International Labour Organisation), Resolution of The 16th International Confrence Of Labour Statisticians, 1998.

[24] BLS (Bureau of Labor Statistics, U.S. Department of Labor), www.bls.gov/iif/oshsum.htm, 2004-2010. 